\title{
JOURNAL.RU
}

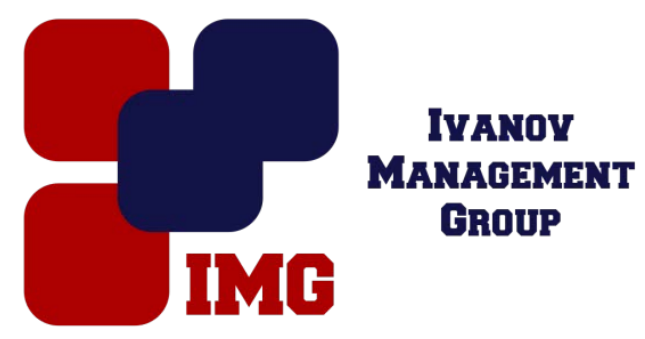

Лукьянова В.О. Саратовский государственный технический университет имени Гагарина Ю.А Саратов, Россия

doi: 10.18411/lj-31-10-2016-1-07

idsp 000001:lj-31-10-2016-1-07

\section{Методологические проблемы изучения глобальной лексики}

Дерматоскоп является неинвазивным инструментом для выявления поражений кожного покрова. Для получения изображения глубоких слоев кожи используют кросс-поляризованный дерматоскоп.

В настоящий момент известно несколько конструкций дерматоскопа, работающих в режиме кросс-поляризации. Недостатком конструкций, описанных в [1, 2], является отсутствие рукоятки. Поскольку во время работы с дерматоскопом врач не может зафиксировать определенное положение прибора, это приводит к ограничению возможностей исследования кожного покрова и, как следствие, к неправильной поставке диагноза.

Цель настоящей работы: упростить работу с дерматоскопом при диагностике кожи в неполяризованном видимом диапазоне, а также в режиме кросс-поляризационного света.

Предлагаемый дерматоскоп содержит следующие элементы (Рис.1): 1 рукоятка, 2 - металлический корпус, 3 - разъём для подключения видеолапароскопа, 4 - вкладыш кросс-поляризованного света, 5 поляризационная пленка, 6 - обратная воронка. Дерматоскоп состоит из металлического корпуса 2 представленного в виде рукоятки соединенной с рабочим элементом под углом 120 градусов. Рукоятка покрыта прорезиненным нескользящим материалом или силиконом. Рабочий элемент выполнен в виде несъёмного тубуса, в котором находится основная оптическая система, состоящая из источника света и светодиодной матрицы с поляризационными 
светодиодами (вкладыш кросс-поляризованного света) 4. Светодиоды подключены к разъему блока питания компьютера, с напряжением 5 В. Один конец тубуса покрыт поляризационной пленкой 5, к этому же концу прикреплена обратная воронка 6, она предназначена для контакта с кожей, при этом исключается вибрация при обследовании. На другом конце тубуса расположен разъем 3 для подключения устройства для визуализации изображения.

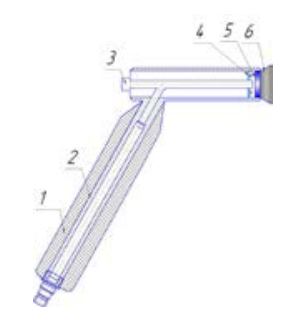

1

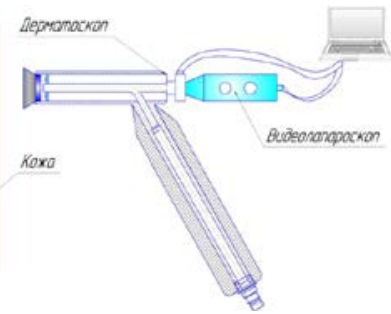

2

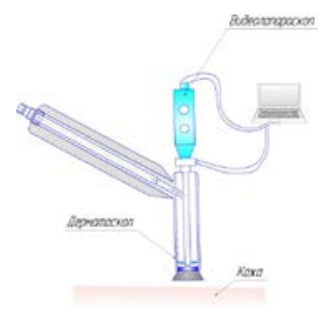

3

Рис.1. Предлагаемая конструкция дерматоскопа (1) и его горизонтальное (2) и вертикальное (3) расположение относительно кожи

Использование видеолапароскопа позволит увеличить резкость изображения и дополнительно осветить рабочее пространство. Предлагаемая система, состоящая из дерматоскопа и устройства для визуализации изображения, выполнена с возможностью подключения к компьютеру. Такое расположение приборов позволит моментально проводить компьютерный анализ полученных снимков с помощью специального программного обеспечения. За счет формы конструкции дерматоскопа им легко будет манипулировать во время исследования морфологии кожи. 


\section{Литература}

1. Патент РФ на изобретение №2459572 от 17.03.2011. Дерматоскоп. Автор: Сергеев В.Ю. Опубл. 27.08.2012.

2. Патент РФ на полезную модель № 161451 от 23.10.2015. Дерматоскоп. Авторы: Смирнов С. В., Поповец Г. И., Плавник Р.Г., Аракчеев А.Г., Новиков Е.В., Баланов М.Ю. Опубл. 20.04.2016. 